\title{
放電加工の進化と挑戦
}

\section{II $>$ \\ ふれまわり放電加工による \\ 小径穴内面テクスチャリング* \\ Micro-structuring on Inner Surface of Small Hole with Whirling Electrical Discharge Texturing}

\section{太田 稔** \\ Minoru OTA}

Key words micro-structuring, whirling electrical discharge texturing, inner surface, friction characteristics

\section{1.は じめに}

部品表面に微細構造を施すことによって, トライボロジ 機能, 熱機能, 光学機能, 電磁気機能などの表面機能を制 御する技術が注目されている。部品表面に微細テクスチャ を加工する方法としては, 切削・研削加工, ブラスト加 工, 塑性加工などの機械的なエネルギーを用いる方法か ら, レーザー加工, 放電加工, 電解加工, エッチングなど の熱エネルギーや化学反応を利用した方法など多くの方法 が考えられる。しかしながら, 焼入れ鋼などの高硬度材料 でできた部品の小径穴内面に対しては, 加工エネルギーや 作業スペースによる理由から, 微細テクスチャリングの方 法が制限される。そこで，筆者らは，小径穴の内面にも微 細テクスチャを施すことができる，ふれまわり放電加工に よる微細テクスチャリング法を開発した1) 3)，本稿では， 開発したふれまわり微細テクスチャリング法の概要, テク スチャリング特性㧍よびテクスチャ表面性状などについて 述べる。

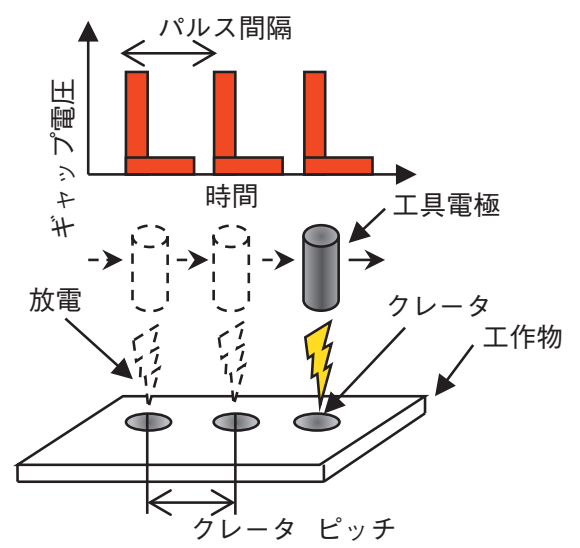

図 1 パルス放電によるクレータ形成

*原稿受付 平成 27 年 8 月 22 日

*正 会 員 京都工芸繊維大学機械工学系 (京都市左京区松ヶ崎御所海道町)

\section{2. ふれまわり放電テクスチャリング装置の開発}

放電加工では単発放電よって放電痕（以下，クレータ） が発生し, 加工面は梨地状になる。梨地状の加工面に扔い ては, クレータの密度を制御することは極めて困難であ る。摩擦係数を制御するために, クレー夕の密度を制御す ることは有効であるが，そのためには，単発放電の回数や エネルギーを制御する必要がある。图 1 に, 単発放電に よる平坦面へのクレータ形成の概念を示す，相対運動する 工具電極と工作物の間に単発放電を発生させ，パルス間隔 を適度に設定することによって, 移動速度とパルス間隔に よって制御されるクレータが形成される。所望の表面全面 にわたって走査を行えば, 表面にテクスチャが創成され る。この方法を放電テクスチャリング (Electrical Discharge Texturing, EDT) と呼ぶ.しかしながら, EDT では，工具電極と工作物間の放電間隙をきちんと制 御しなければならず，高度な制御装置を必要とする。そこ で，厳密な放電間隙の制御を必要としない方法として，ふ れまわり放電現象を応用した，ふれまわり放電テクスチャ リング (Whirling Electrical Discharge Texturing, WEDT) 法を考案した。この方法は, 図 2 に示すように, 軸を回

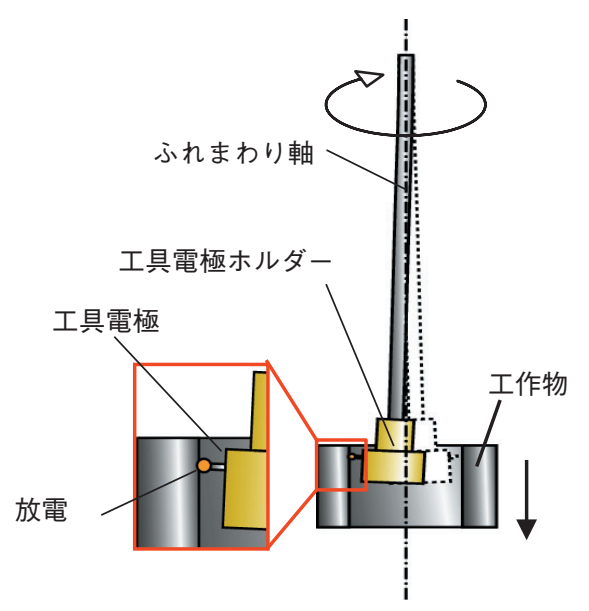

図 2 軸のふれまわり現象を利用した放電加工の概念 


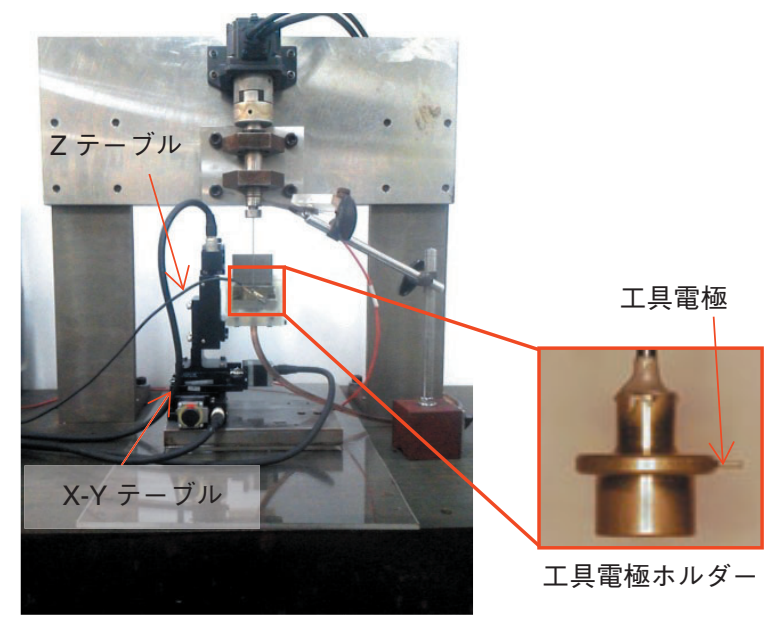

図３永れまわり放電テクスチャリング装置

転させることによってふれまわり現象を起こさせ，工具電 極先端と工作物内面との間で発生した単発放電によって, 工作物表面にクレータを形成しようとするものである。し かしながら実際には，必ずしも計算されたパルス放電間隔 で放電が発生するわけではなく，また，ふれまわり現象に よる工具電極先端の振れの大きさも一定に制御できるわけ ではなく，ある程度のばらつきをもっている。このばらつ き（あいまいさ）が，小径穴内面の形状精度のばらつきと 相まって, クレータの大きさや深さ，さらには密度分布が ランダムなテクスチャを形成することになる。すなわち， WEDT による微細テクスチャは分布状態と個々のクレー 夕形状がそれぞればらつきをもつランダム・テクスチャと なる。

図 3 に，製作したふれまわり放電加工装置を示す。モ ータに直結したスピンドル先端にコレットチャックを装着 し，タングステン製のふれまわり軸を絶縁体を介して把持 する。ふれれわり軸先端には，工具電極ホルダーが取り付 けられ，ホルダーに直径 $\phi 0.3 \mathrm{~mm}$ のタングステンワイヤ が装着されている，X-Yテーブルで位置決めを行い，Z 軸テーブルで工作物を軸方向に移動させる，放電電源によ り, 印加する電圧值, 電流值, 放電時間等の制御を行い, モー夕回転数の制御とZテーブル軸方向送り速度の制御 を合わせることによって，さまざまなクレー夕密度，クレ 一夕の大きさ等の制御が可能である.

\section{3. ふれまわり放電テクスチャリング特性}

開発したふれまわり放電テクスチャリング装置を用い て, 放電加工条件や工作物速度を変えて加工した，加工後 の工作物の表面状態を観察・解析することにより，テクス チャリング特性を把握した。テクスチャ面の観察は，工作 物を半割に切断し、デジタルマイクロスコープ (Hirox, KH-1300), SEM（JEOL, JSM-7001F），あるいは非接触 3 次元表面形状・粗さ測定機（ZYGO, NewView 7300）を 用いて行った。

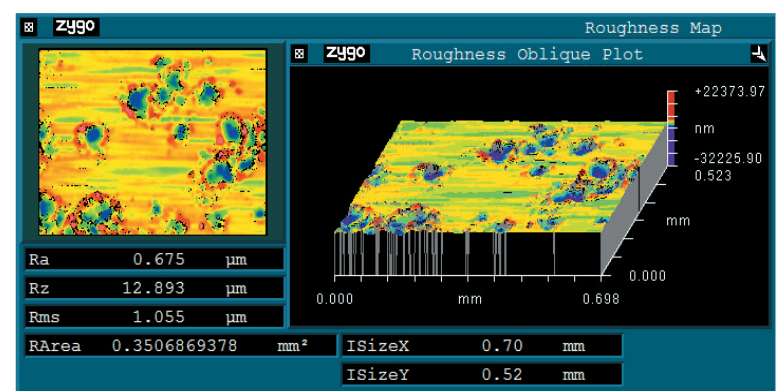

図 4 テクスチャ表面観察の例 (ZYGO NewView 7300)

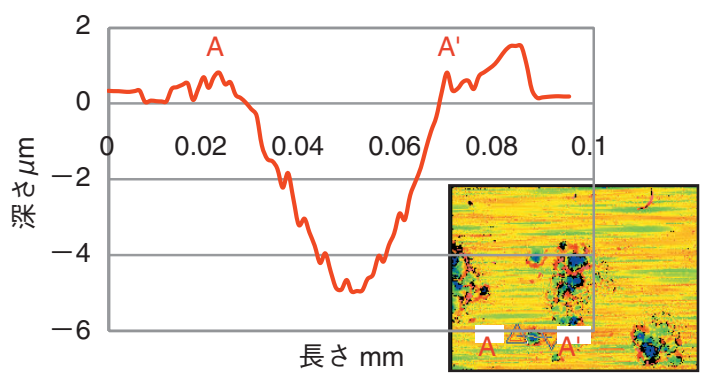

図 5 クレータの断面プロファイルの例

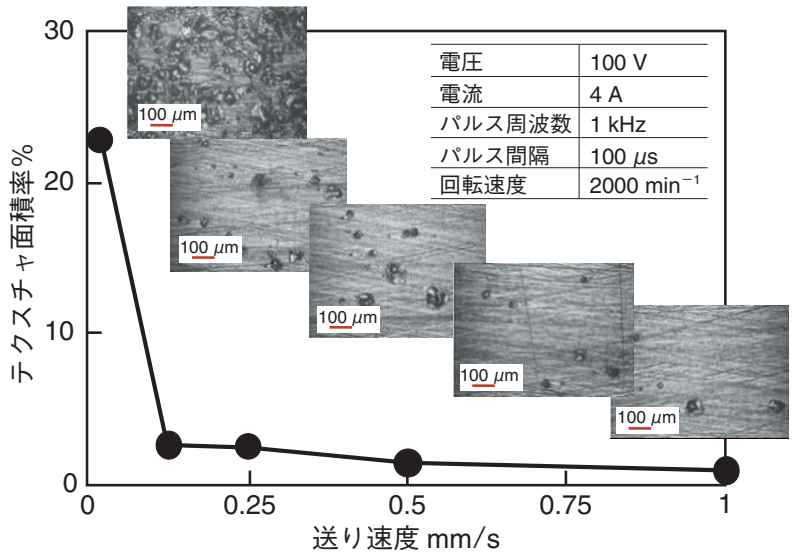

図 6 送り速度とテクスチャ面積率

テクスチャを施した表面から任意の箇所を抽出し，非接 触 3 次元表面形状 - 粗さ測定機を用いて観察・解析した代 表的な例を图 4 に示す。また，図 5 にクレータの断面プ ロファイルを示す。ランダムなクレータが形成されてお り, クレー夕周辺部には盛り上がりが生じていることがわ かる。このような盛り上がり部は, 表面粗さの悪化を招 き, 摩擦係数を増大させるため, テクスチャリング後に表 面仕上げを行い除去する必要がある。

次に, 測定したクレータ部の総面積が測定表面積に占め る割合（これをテクスチャ面積率と呼ぶ）を評価した。工 作物送り速度とテクスチャ面積率の関係を図 6 に示す。 図中には，工作物表面の顕微鏡写真を合わせて示す．工作 


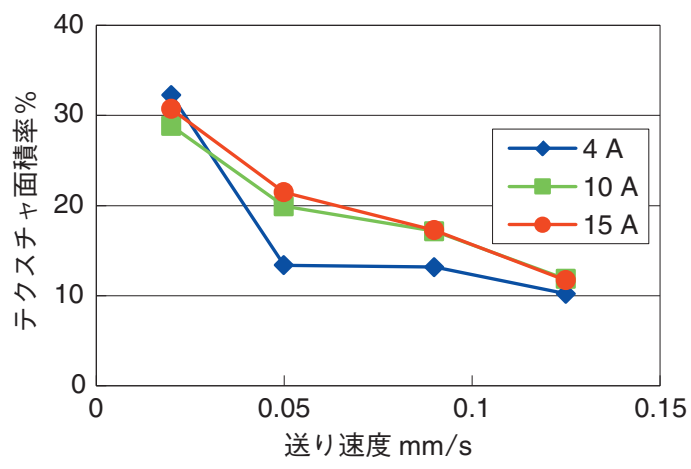

図 7 送り速度とテクスチャ面積率

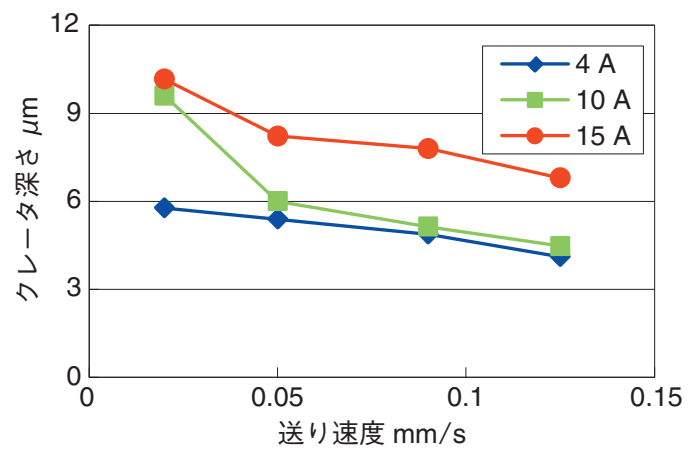

図 8 送り速度とクレータ深さ

物送り速度の増大に伴ってテクスチャ面積率は減少した。 特に，工作物送り速度が $0.125 \mathrm{~mm} / \mathrm{s}$ から $0.00167 \mathrm{~mm} / \mathrm{s}$ に減少する際に，テクスチャ面積率が急激に増大している ことがわかる。これは，工作物送り速度が小さくなると， クレータ周辺の盛り上がり部との放電間隙が小さくなり放 電が集中することが原因と考えられる。

図 6 の結果から, 工作物送り速度によってテクスチャ面 積率を制御できる可能性が示された。また，得られたテク スチャ面積率は，打打よそのクレータの大きさとともに， 摩擦係数を低減できる可能性がある範囲を含むものと考元 られた。そこで，より詳細に，加工条件とテクスチャ表面 性状の関係を検討した。図 6 の結果から, 工作物送り速度 は急激な変化が現れた低送り速度領域の条件とした。

表面性状の観察結果から，工作物送り速度とテクスチャ 表面性状の関係を整理した。図 7 に，工作物送り速度と テクスチャ面積率の関係を示す。いずれの放電電流值に扔 いても，工作物送り速度の減少とともにテクスチャ面積率 は大きくなった，すなわち，工作物送り速度および放電電 流によってテクスチャ面積率が制御できることが示され た。図 8 に，工作物送り速度とクレー夕深さの関係，図 9 に，クレータ直径との関係をそれぞれ示す。クレー夕深さ およびクレー夕直径とも，工作物送り速度が小さくなると ともに，徐々に増大している，また，放電電流が大きくな るとクレータ深さ，クレータ直径ともに増大している。こ れは，工作物送り速度や放電電流が大きくなると放電工ネ

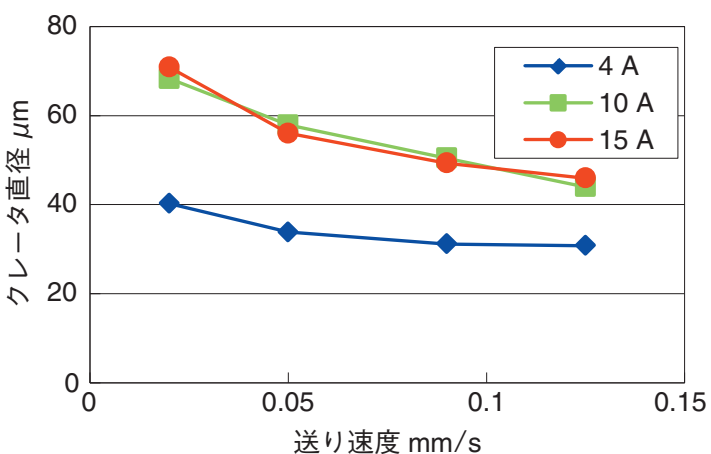

図 9 送り速度とクレータ直径
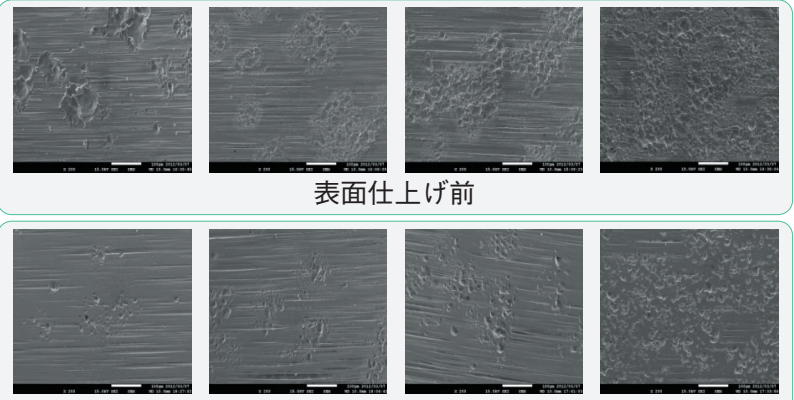

(a) $0.125 \mathrm{~mm} / \mathrm{s}$ (b) $0.09 \mathrm{~mm} / \mathrm{s}$ (c) $0.05 \mathrm{~mm} / \mathrm{s}$

(d) $0.02 \mathrm{~mm} / \mathrm{s}$ 表面仕上げ後

図 10 表面仕上げ前後のテクスチャ表面状態

ルギーが大きくなるためと考えられる。しかしながら, 図 8 や図 9 に打いて, 電流值とクレー夕深さやクレー夕直径 の関係は, 必ずしも一定の傾向を示すとは限らず, ばらつ きが生じている。この原因として，実験ごとのふれまわり 挙動のばらつきや工具電極の突出し量の変化などが起因し ているものと考えられる.

\section{4. 表面仕上げ後のテクスチャ表面性状}

前述のように，放電テクスチャリング後にはクレータ周 辺に数 $\mu \mathrm{m}$ 程度の盛り上がりが発生する。この盛り上がり 部は摩擦係数の低減にとって重大な悪影響を及ぼす。その ため, 放電テクスチャリング後には必ず盛り上がり部を除 去するための表面仕上げが必要となる。そこで, 放電テク スチャリング後, 半割した工作物内面を平均粒径 $2 \mu \mathrm{m}$ の アルミナラッピングフィルムを用いて表面仕上げを行い， 盛り上がり部除去前と除去後の表面性状を比較した。 図 10 に放電電流 $4 \mathrm{~A}$ のときの表面仕上げ後の表面 SEM 写 真を示す．表面仕上げによって盛り上がり部が除去されて いることがわかる。一方で，クレー夕直径やクレータ深さ も小さくなっていることが伺える. 図 11 に工作物送り速 度とテクスチヤ面積率の関係を示す。テクスチヤ面積率は 表面仕上げ前後で大きく変化していない，これは，クレー 夕面積率が表面とほぼ同一面のクレータ口元の面積を測定 しているため, 表面仕上げによって盛り上がり部が優先的 


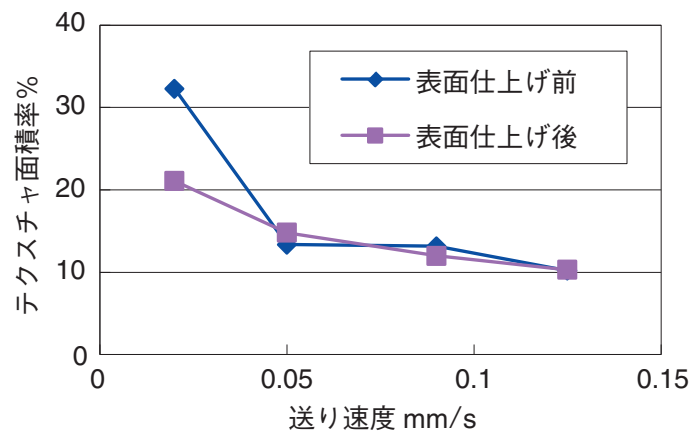

図 11 送り速度と表面仕上げ前後のテクスチャ面積率

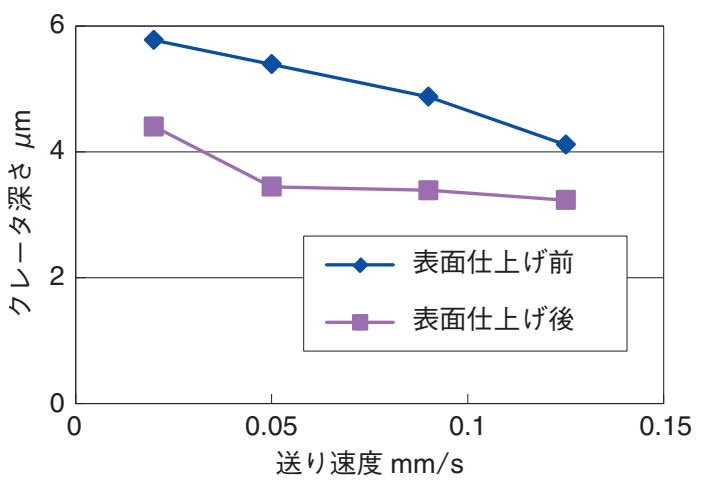

図 12 送り速度と表面仕上げ前後のクレータ深さ

に除去された結果と考えられる。図 12 に工作物送り速度 とクレータ深さとの関係を示す. クレータ深さは表面仕上 げによって大きく変化し, 表面仕上げ代相当の深さが減少 している. 本実験では, $1 \sim 2 \mu \mathrm{m}$ 程度の除去量で表面仕上 げが行われていることがわかる。しかしながら，クレータ 直径は表面仕上げ前後で大きく変化しなかった。これは, テクスチャ面積率の結果からも理解できる.

\section{5. 放電テクスチャによる摩擦低減効果}

これまで, 放電テクスチャリングによる基本的な加工特 性について述べてきた。ここでは, 放電テクスチャを施し た表面の摩擦特性の評価の例として, ボールオンデイスク 試験による結果を述べる。図13 は, テクスチャを施して いない試験片（テクスチャなし）と 3 種類のテクスチャ面 積率で加工した試験片（4\%，6\%，12\%）に扔いて，摺動 速度ごとの摩擦係数を測定した結果である。テクスチャな しに対して, テクスチャありの場合には, テクスチャ面積 率によって摩擦係数の低減効果に差があった。すなわち, テクスチャ面積率 4\%, 12\% の試験片では，テクスチャな しの試験片より摩擦倸数は大きくなり，6\%の試験片では 小さくなった。これは, テクスチャ面積率によって, 真実 接触面の圧力変化拧よびクレータの油保持能力の変化の相

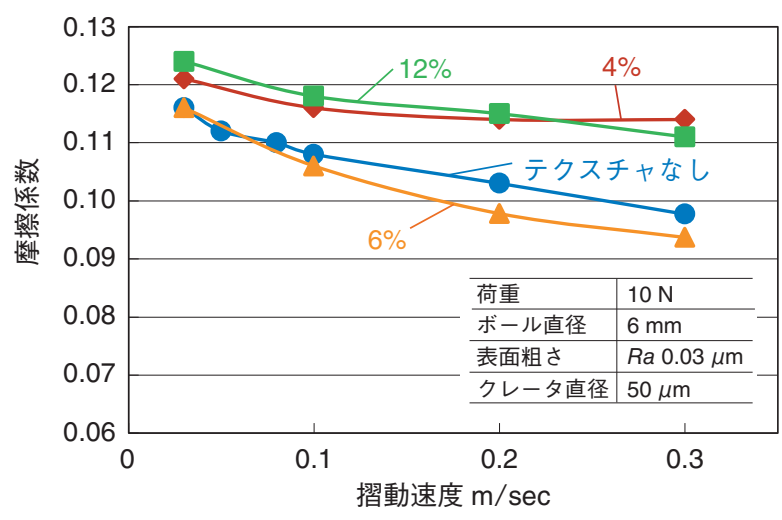

図 13 放電テクスチャによる摩擦低減効果

乗作用によって, 油膜形成能力が決定されるためと考えら れる，すなわち，摺動条件によって最適なテクスチャ表面 性状が存在するということであり, テクスチャの摩擦低減 効果を体系的に論じるためには, 今後多くの詳細な検討が 必要であろう。

\section{6.おわりに}

ふれまわり放電加工による小径穴内面のテクスチャリン グについて，開発したテクスチャリング法の概要，テクス チャリング特性，扔よび摩擦特性の評価の一例についても 述べてきた，今後，さらに詳細にテクスチャ表面性状と摩 擦特性の関倸を検討し, 硬質小径穴内面の摩擦特性の改善 を図って行きたい，本稿が表面機能制御技術の進展の参考 になれば幸いである。

\section{参 考 文 献}

1) V. Lertphokanont, et. al. : Surface Quality of Textured Surface on Cylindrical Inner Surface Using Whirling Electrical Discharge Texturing, Advanced Materials Research, 797 (2013).

2) V. Lertphokanont, et al. : Development of Whirling Electrical Discharge Texturing on Inner Surface of Small Hole, Journal of Advanced Mechanical Design, Systems, and Manufacturing, 7, 4 (2013).

3) V. Lertphokanont, et al. : Effect of Discharge Duration and Pulse Frequency on Surface Characteristics of Textured Surface Using Whirling Electrical Discharge Texturing, Proceedings of the 7th International Conference on Leading Edge Manufacturing in 21st Century, (2013).

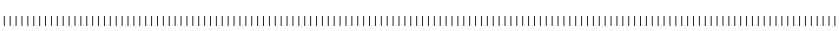

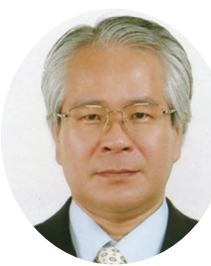
太田 稔

1997 年東北大学大学院工学研究科博士後期課程 修了. 博士 (工学). 研究内容は微細加工による 高機能表面創成に関する研究, 超多機能多工程 集約複合加工機の開発。著書は「微細構造から 考える表面機能」(森北出版) など.

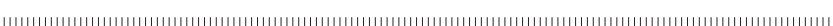

